\title{
Effect of Sowing Dates and Varieties on Economics and Nutrient Status of Direct Seeded Rice (Oryza sativa L.) and Soil
}

\author{
C. M. Shanta ${ }^{1 *}$, Y. M. Ramesha ${ }^{1}$, D. Krishnamurthy ${ }^{1}$, \\ M. R. Umesh ${ }^{1}$ and Manjunatha Bhanuvally ${ }^{5}$ \\ ${ }^{1}$ Department of Agronomy, University of Agricultural Sciences, Raichur, \\ Karnataka 584 101, India \\ ${ }^{2}$ Department of Soil Science and Agriculture Chemistry, University of Agricultural sciences, \\ Raichur, Karnataka 584 101, India \\ *Corresponding author
}

\begin{abstract}
A B S T R A C T
Sowing time of rice sometimes get delayed due to lack of assured irrigation or surplus of rainfall. Moreover, no specific varieties have been specifically developed for this purpose. An experiment was conducted to study the effect of sowing dates and varieties on economics and soil properties of direct seeded rice in 2018 at Agricultural Research Station, Dhadesugur in Karnataka. The experimental site was medium black clay soil belonging to the order vertisol with soil $\mathrm{pH}(8.10)$, EC $\left(0.65 \mathrm{dS} \mathrm{m} \mathrm{m}^{-1}\right)$, available nitrogen $\left(244.60 \mathrm{~kg} \mathrm{ha}^{-1}\right), \mathrm{P}_{2} \mathrm{O}_{5}\left(37.50 \mathrm{~kg} \mathrm{ha}^{-1}\right)$ and $\mathrm{K}_{2} \mathrm{O}\left(336.3 \mathrm{~kg} \mathrm{ha}^{-1}\right)$. The experiment comprised of five dates of sowing viz., $\mathrm{D}_{1}: 2^{\text {nd }}$ Fortnight of June, $\mathrm{D}_{2}: 1^{\text {st }}$ Fortnight of July, $\mathrm{D}_{3}: 2^{\text {nd }}$ Fortnight of July, $\mathrm{D}_{4}: 1^{\text {st }}$ Fortnight of August and $\mathrm{D}_{5}: 2^{\text {nd }}$ Fortnight of August and four varieties viz., $\mathrm{V}_{1}$ : GGV- 05- 01, $\mathrm{V}_{2}$ : RNR-15048, $\mathrm{V}_{3}$ : BPT-5204 and $\mathrm{V}_{4}$ : GNV-10-89. These treatments were laid out in split plot design with three replications. The experimental results revealed that, $2^{\text {nd }}$ fortnight of June recorded higher NPK content and uptake (117.8, 39.3 and $124.1 \mathrm{~kg} \mathrm{ha}^{-1}$, respectively), whereas higher available NPK was recorded by crop sown on $2^{\text {nd }}$ Fortnight of August $\left(242.4,46.53\right.$, and $305.9 \mathrm{~kg} \mathrm{ha}^{-1}$, respectively). Cost of cultivation of each crop was worked out and income of crop yields was calculated on prevailing market prices. Among the different treatment combinations, $\mathrm{D}_{1} \mathrm{~V}_{2}$ recorded significantly higher gross returns (Rs. 1,31,564 ha $\mathrm{h}^{-1}$ ), net returns (Rs. $75,550 \mathrm{ha}^{-1}$ ) and BCR (2.35) which was on par with $\mathrm{D}_{2} \mathrm{~V}_{2}$ (Rs. 1,30,502 ha ${ }^{-1}, 74,488 \mathrm{ha}^{-1}$ and 2.33 , respectively).
\end{abstract}

\section{Keywords}

Direct seeded rice (DSR), Dates of sowing, Varieties, economics and Uptake

\section{Article Info}

Accepted: 14 June 2020 Available Online: 10 July 2020

\section{Introduction}

Rice (Oryza sativa L.) is the world's third largest crop after maize and wheat. It is the staple food for more than half of the world's population. Rice cultivation is the principal activity and source of income for about 100 million households and its demand will continue to expand due to population growth and increasing consumption patterns in different regions [FAO, 2004]. In Karnataka, rice is grown in an area of 1.36 million 
hectare with a production of 3.99 million tonnes and the productivity of 3.10 tonnes per hectare (Anon., 2018). More than 80 per cent of the developed fresh water resources in Asia are used for irrigation purposes and consumes up to 43 per cent of the world's developed irrigation resources (Bouman et al., 2007).

The common method of rice cultivation in India is transplanting the nursery which is very laborious and time consuming. To address these problems, direct seeded rice is evolved. Direct sowing method is the new development in water saving techniques, where rice is grown like other cereal crop with supplemental irrigation. DSR is considered as water saving technology which can help to overcome the present water scarcity and nutrient loss. Time of sowing is one of the critical aspects of direct seeding of rice and determines the productivity of a crop.

Optimum sowing time for a crop is location specific. Production of direct seeded rice decreases if there is delay in sowing. However, at the same time, no varieties have been specifically developed for this purpose.

Rice varieties vary in their seedling vigor, weed competitiveness, submergence and drought tolerance, maturity duration, lodging resistance, affecting the resource utilization and productivity. Not much information is available on suitable varieties and crop establishment practices for direct seeding in comparison to traditional method. Viewing these facts, a field experiment was conducted to evaluate the effectiveness of sowing dates and varieties on economics and nutrient status of direct seeded rice and in soil.

\section{Materials and Methods}

A field experiment was carried out at Agriculture Research Station, Dhadesugur in Karnataka during 2018-19 to study on
Response of direct seeded rice (Oryza sativa 1.) to dates of sowing and varieties. The centre is located in agro-climatic zone III (Northern Dry zone) of Karnataka. The station is situated at latitude of $15^{\circ} 69^{\prime} \mathrm{N}$ and $76^{\circ} 89^{\prime} \mathrm{E}$ longitude with an altitude of $358 \mathrm{~m}$ above mean sea level.

The experimental site was medium black clay soil belonging to the order vertisol with soil $\mathrm{pH}$ (8.10), EC (0.65 $\left.\mathrm{dS} \mathrm{m}^{-1}\right)$, available nitrogen $\left(244.60 \mathrm{~kg} \mathrm{ha}^{-1}\right), \mathrm{P}_{2} \mathrm{O}_{5}\left(37.50 \mathrm{~kg} \mathrm{ha}^{-1}\right)$ and $\mathrm{K}_{2} \mathrm{O}\left(336.3 \mathrm{~kg} \mathrm{ha}^{-1}\right)$.

The experiment comprised of five dates of sowing viz., $\mathrm{D}_{1}: 2^{\text {nd }}$ Fortnight of June, $\mathrm{D}_{2}: 1^{\text {st }}$ Fortnight of July, $\mathrm{D}_{3}$ : $2^{\text {nd }}$ Fortnight of July, $\mathrm{D}_{4}: 1^{\text {st }}$ Fortnight of August and $\mathrm{D}_{5}: 2^{\text {nd }}$ Fortnight of August and four varieties viz., $\mathrm{V}_{1}$ : GGV- 05- 01, $\mathrm{V}_{2}$ : RNR-15048, $\mathrm{V}_{3}$ : BPT5204 and $\mathrm{V}_{4}$ : GNV-10-89. Crop was sown with the spacing of $20 \mathrm{~cm}$ between the rows in $6 \times 4$ m plot. As split-split plot design with three replications was used, dates of sowing were allocated to the main plots while rice varieties in the sub plots. These treatments were laid out in split plot design with three replications.

The recommended dose of fertilizer to each crop was applied at the rate of $150: 75: 75 \mathrm{~kg}$ $\mathrm{N}, \mathrm{P}_{2} \mathrm{O}_{5}, \mathrm{~K}_{2} \mathrm{O} \mathrm{ha}^{-1}$ in the form of urea, diammonium phosphate and muriate of potash, respectively. Entire quantity of phosphorus, potassium and 50 per cent of nitrogen were applied at the time of sowing. Remaining 50 per cent of nitrogen was applied as two splits, one at tillering stage and other at panicle initiation (PI) stage. Farmyard manure at 5 tonnes per hectare was applied one week before sowing and incorporated into the soil before passing the cultivator.

Data were collected on nitrogen, phosphorous and potassium content, NPK uptake, available nitrogen, phosphorous and potassium in soil, 
cost of cultivation, gross returns, net returns and benefit-cost ratio. NPK analysis was done by using micro-kjeldhal's method, vanadomolybodo phosphoric acid yellow color method and flame photometer method, respectively. With the help of NPK content and biomass yield NPK uptake was calculated. The statistical analysis for various characters under investigation was done.

\section{Results and Discussion}

Nutrient status of direct seeded rice and soil after harvest

Nutrient status and economics of direct seeded rice differed significantly as influenced by different varieties under varied dates of sowing. The results revealed that the crop sown on $2^{\text {nd }}$ Fortnight of June recorded higher nitrogen, phosphorous and potassium content $(2.11,0.74$ and $2.94 \%$, respectively) and also its uptake (117.8, 39.3 and $124.1 \mathrm{~kg}$ $\mathrm{ha}^{-1}$ of NPK, respectively) and is presented in the table 1 and 2, respectively. Whereas, crop sown on $2^{\text {nd }}$ fortnight of August recorded lower nitrogen, phosphorous and potassium content $(1.91,0.56$ and $2.59 \%$, respectively) and also its uptake $(77.5,22.0$ and $77.5 \mathrm{~kg} \mathrm{ha}$ ${ }^{1}$ of NPK, respectively).

Higher dry matter accumulation and availability of nutrients might be the reason for higher NPK content of the variety GGV05-01 and crop sown on $2^{\text {nd }}$ fortnight of June. Similar results were obtained by Chamely et al., 2014.

Among different varieties, GGV-05-01 recorded higher NPK content (2.20, 0.79 and $3.09 \%$, respectively) and uptake (119.4, 40.5 and $127.3 \mathrm{~kg} \mathrm{ha}^{-1}$, respectively), whereas BPT-5204 recorded lower NPK content (1.83, 0.52 and $2.48 \%$, respectively) and uptake $\left(85.4,23.5\right.$ and $85.7 \mathrm{~kg} \mathrm{ha}^{-1}$, respectively). It is clear that nutrient uptake also depends on the varieties. As there was higher biomass and NPK content, higher uptake was observed. Higher available NPK in soil was observed, where crop was sown on $2^{\text {nd }}$ fortnight of August (242.4, 46.53, and $305.9 \mathrm{~kg} \mathrm{ha}^{-1}$, respectively), while lower available NPK in soil was observed, where crop was sown on $2^{\text {nd }}$ fortnight of June $(210.5,35.3$, and 282.4 $\mathrm{kg} \mathrm{ha}^{-1}$, respectively).

As there was better uptake of the nutrients in early sown direct seeded rice, available nutrients in soil at harvest decreased. In the same way, when varieties are considered available NPK in soil was lower in the treatment of GGV-05-01 (207.5, 35.3 and 282 $\mathrm{kg}$ NPK $\mathrm{ha}^{-1}$, respectively), while available NPK in the treatment of variety BPT-5204 (241.6, 45.5 and $302.2 \mathrm{~kg}$ NPK $\mathrm{ha}^{-1}$, respectively). Thus, crop variety GGV-05-01 sown on $2^{\text {nd }}$ fortnight of June is considered to be the best treatement with respect to nutrient availability.

\section{Economics of direct seeded rice}

Labour saving of Direct Seeded Rice reduces 11.2 per cent of total production cost as well as Direct Seeded Rice methods have several advantages over transplanting (Singh et al., 2005; Naresh et al., 2010). Economics is the main parameter which finally decides the adoption levels at farming situations of any newly introduced technology by the farmers. A new technology should be technically and economically viable.

Therefore, the economic analysis of the results is very important. In addition to higher economic returns, Direct Seeded Rice crops are faster and easier to plant and less labor intensive (Jehangir et al., 2005). In this experiment, the cost of cultivation was similar for all treatments (Rs. $56014 \mathrm{ha}^{-1}$ ) except for the treatments where BPT-5204 (Rs. 61,014 $\mathrm{ha}^{-1}$ ) was grown as it was attacked by BPH. 
Table.1 NPK content of direct seeded rice as influenced by different varieties under varied dates of sowing

\begin{tabular}{|c|c|c|c|c|c|c|c|c|c|c|c|c|c|c|c|c|c|c|}
\hline \multirow{2}{*}{$\begin{array}{c}(\mathbf{D}) / \\
(\mathbf{V})\end{array}$} & \multicolumn{5}{|c|}{ Nitrogen (\%) } & \multirow[t]{2}{*}{ Mean } & \multicolumn{5}{|c|}{ Phosphorous (\%) } & \multirow{2}{*}{ Mean } & \multicolumn{5}{|c|}{ Potassium (\%) } & \multirow[t]{2}{*}{ Mean } \\
\hline & $\mathbf{D}_{1}$ & $\mathbf{D}_{2}$ & $\mathbf{D}_{3}$ & $\mathbf{D}_{4}$ & $\mathbf{D}_{5}$ & & $\mathbf{D}_{1}$ & $\mathbf{D}_{2}$ & $\mathbf{D}_{3}$ & $\mathbf{D}_{4}$ & $\mathrm{D}_{5}$ & & $\mathrm{D}_{1}$ & $\mathbf{D}_{2}$ & $\mathbf{D}_{3}$ & $\mathbf{D}_{4}$ & $\mathbf{D}_{5}$ & \\
\hline $\mathbf{V}_{1}$ & 2.29 & 2.24 & 2.21 & 2.17 & 2.09 & 2.20 & 0.879 & 0.828 & 0.790 & 0.736 & 0.700 & 0.79 & 3.22 & 3.15 & 3.13 & 3.00 & 2.94 & 3.09 \\
\hline $\mathbf{V}_{2}$ & 2.06 & 2.02 & 2.00 & 1.96 & 1.87 & 1.98 & 0.700 & 0.654 & 0.621 & 0.544 & 0.521 & 0.61 & 2.85 & 2.79 & 2.71 & 2.58 & 2.49 & 2.69 \\
\hline $\mathbf{V}_{3}$ & 1.93 & 1.89 & 1.85 & 1.80 & 1.70 & 1.83 & 0.608 & 0.565 & 0.531 & 0.464 & 0.424 & 0.52 & 2.65 & 2.58 & 2.52 & 2.37 & 2.26 & 2.48 \\
\hline $\mathbf{V}_{4}$ & 2.18 & 2.13 & 2.11 & 2.06 & 1.97 & 2.09 & 0.780 & 0.732 & 0.693 & 0.630 & 0.592 & 0.69 & 3.02 & 2.96 & 2.90 & 2.76 & 2.68 & 2.87 \\
\hline \multirow[t]{2}{*}{ Mean } & 2.11 & 2.07 & 2.04 & 2.00 & 1.91 & & 0.74 & 0.69 & 0.66 & 0.59 & 0.56 & & 2.94 & 2.87 & 2.82 & 2.68 & 2.59 & \\
\hline & \multicolumn{3}{|c|}{ SEm \pm} & \multicolumn{3}{|c|}{ C.D $(p=0.05)$} & \multicolumn{3}{|c|}{ SEm \pm} & \multicolumn{3}{|c|}{ C.D $(p=0.05)$} & \multicolumn{3}{|c|}{ SEm \pm} & \multicolumn{3}{|c|}{ C.D $(p=0.05)$} \\
\hline D & \multicolumn{3}{|c|}{0.01} & \multicolumn{3}{|c|}{0.04} & \multicolumn{3}{|c|}{0.02} & \multicolumn{3}{|c|}{0.04} & \multicolumn{3}{|c|}{0.02} & \multicolumn{3}{|c|}{0.06} \\
\hline $\mathbf{V}$ & \multicolumn{3}{|c|}{0.01} & \multicolumn{3}{|c|}{0.04} & \multicolumn{3}{|c|}{0.01} & \multicolumn{3}{|c|}{0.04} & \multicolumn{3}{|c|}{0.03} & \multicolumn{3}{|c|}{0.09} \\
\hline D X V & \multicolumn{3}{|c|}{0.02} & \multicolumn{3}{|c|}{ NS } & \multicolumn{3}{|c|}{0.02} & \multicolumn{3}{|c|}{ NS } & \multicolumn{3}{|c|}{0.04} & \multicolumn{3}{|c|}{ NS } \\
\hline
\end{tabular}

D: Dates of sowing
$\mathrm{D}_{1}: 2^{\text {nd }}$ Fortnight of June
$\mathrm{D}_{2}: 1^{\text {st }}$ Fortnight of July
$\mathrm{D}_{3}: 2^{\text {nd }}$ Fortnight of July
$\mathrm{D}_{4}: 1^{\text {st }}$ Fortnight of August

$$
\begin{gathered}
\mathrm{V}_{1}: \text { GGV-05-01 } \\
\mathrm{V}_{2}: \text { RNR -15048 } \\
\mathrm{V}_{3}: \text { BPT -5204 } \\
\mathrm{V}_{4}: \text { GNV-10-89 }
\end{gathered}
$$

\begin{tabular}{|c|c|c|c|c|c|c|c|c|c|c|c|c|c|c|c|c|c|c|}
\hline \multirow{2}{*}{$\begin{array}{l}\text { (D) / } \\
\text { (V) }\end{array}$} & \multicolumn{5}{|c|}{ Nitrogen $\left(\mathrm{kg} \mathrm{ha}^{-1}\right)$} & \multirow[t]{2}{*}{ Mean } & \multicolumn{5}{|c|}{ Phosphorous ( $\mathrm{kg} \mathrm{ha}^{-1}$ ) } & \multirow[b]{2}{*}{ Mean } & \multicolumn{5}{|c|}{ Potassium ( $\left.\mathrm{kg} \mathrm{ha}^{-1}\right)$} & \multirow[t]{2}{*}{ Mean } \\
\hline & $\mathbf{D}_{1}$ & $\mathbf{D}_{2}$ & $\mathbf{D}_{3}$ & $\mathbf{D}_{4}$ & $\mathbf{D}_{5}$ & & $\mathbf{D}_{1}$ & $\mathbf{D}_{2}$ & $\mathbf{D}_{3}$ & $\mathbf{D}_{4}$ & $\mathbf{D}_{5}$ & & $\mathbf{D}_{1}$ & $\mathbf{D}_{2}$ & $\mathbf{D}_{3}$ & $\mathbf{D}_{4}$ & $\mathbf{D}_{5}$ & \\
\hline $\mathbf{V}_{1}$ & 132.6 & 129.6 & 124.5 & 119.5 & 90.6 & 119.4 & 47.8 & 45.1 & 42.1 & 38.4 & 28.9 & 40.5 & 143.4 & 138.8 & 133.9 & 124.6 & 95.7 & 127.3 \\
\hline$V_{2}$ & 113.2 & 110.5 & 107.9 & 102.3 & 75.8 & 101.9 & 36.7 & 34.4 & 32.3 & 27.7 & 20.6 & 30.3 & 118.3 & 112.9 & 110.5 & 101.1 & 72.2 & 103.0 \\
\hline $\mathbf{V}_{3}$ & 101.0 & 91.2 & 88.9 & 82.5 & 63.3 & 85.4 & 30.5 & 26.1 & 24.6 & 20.7 & 15.4 & 23.5 & 103.7 & 92.2 & 90.7 & 80.7 & 61.1 & 85.7 \\
\hline$V_{4}$ & 124.5 & 120.9 & 117.6 & 108.2 & 80.1 & 110.3 & 42.1 & 39.7 & 36.7 & 31.8 & 23.3 & 34.7 & 131.1 & 127.1 & 120.7 & 107.9 & 80.9 & 113.6 \\
\hline \multirow[t]{2}{*}{ Mean } & 117.8 & 113.1 & 109.7 & 103.1 & $\mathbf{7 7 . 5}$ & & 39.3 & 36.3 & 33.9 & 29.7 & 22.0 & & 124.1 & 117.7 & 113.9 & 103.6 & 77.5 & \\
\hline & \multicolumn{3}{|c|}{ SEm \pm} & \multicolumn{3}{|c|}{ C.D $(p=0.05)$} & \multicolumn{3}{|c|}{ SEm \pm} & \multicolumn{3}{|c|}{ C.D $(p=0.05)$} & \multicolumn{3}{|c|}{ SEm \pm} & \multicolumn{3}{|c|}{ C.D $(p=0.05)$} \\
\hline D & \multicolumn{3}{|c|}{1.34} & \multicolumn{3}{|c|}{3.88} & \multicolumn{3}{|c|}{0.95} & \multicolumn{3}{|c|}{2.76} & \multicolumn{3}{|c|}{1.67} & \multicolumn{3}{|c|}{4.83} \\
\hline $\mathbf{V}$ & \multicolumn{3}{|c|}{0.90} & \multicolumn{3}{|c|}{2.60} & \multicolumn{3}{|c|}{0.74} & \multicolumn{3}{|c|}{2.14} & \multicolumn{3}{|c|}{1.21} & \multicolumn{3}{|c|}{3.49} \\
\hline D X V & \multicolumn{3}{|c|}{1.16} & \multicolumn{3}{|c|}{ NS } & \multicolumn{3}{|c|}{0.96} & \multicolumn{3}{|c|}{ NS } & \multicolumn{3}{|c|}{1.56} & \multicolumn{3}{|c|}{ NS } \\
\hline
\end{tabular}

$\mathrm{V}$ : Varieties

$D_{5}: 2^{\text {nd }}$ Fortnight of August

Table.2 Uptake of nutrients after harvest of direct seeded rice as influenced by different varieties under varied dates of sowing

V: Varieties

$\begin{array}{lc}\mathrm{D}_{1}: 2^{\text {nd }} \text { Fortnight of June } & \mathrm{V}_{1}: \text { GGV }-05-01 \\ \mathrm{D}_{2}: 1^{\text {st }} \text { Fortnight of July } & \mathrm{V}_{2}: \text { RNR }-15048 \\ \mathrm{D}_{3}: 2^{\text {nd }} \text { Fortnight of July } & \mathrm{V}_{3}: \text { BPT }-5204 \\ \mathrm{D}_{4}: 1^{\text {st }} \text { Fortnight of August } & \mathrm{V}_{4}: \text { GNV }-10-89 \\ \mathrm{D}_{5}: 2^{\text {nd }} \text { Fortnight of August } & \end{array}$

4. 1 Fortnight of August

$\mathrm{V}_{3}$ : BPT -5204

$D_{5}: 2^{\text {nd }}$ Fortnight of August 
Table.3 Soil available nutrients after harvest of direct seeded rice as influenced by different varieties under varied dates of sowing

\begin{tabular}{|c|c|c|c|c|c|c|c|c|c|c|c|c|c|c|c|c|c|c|}
\hline \multirow{2}{*}{$\begin{array}{l}(\mathbf{D}) / \\
(\mathbf{V})\end{array}$} & \multicolumn{5}{|c|}{ Nitrogen $\left(\mathrm{kg} \mathrm{ha}^{-1}\right)$} & \multirow[t]{2}{*}{ Mean } & \multicolumn{5}{|c|}{ Phosphorous ( $\mathrm{kg} \mathrm{ha}^{-1}$ ) } & \multirow[b]{2}{*}{ Mean } & \multicolumn{5}{|c|}{ Potassium ( kg ha ${ }^{-1}$ ) } & \multirow[t]{2}{*}{ Mean } \\
\hline & $\mathbf{D}_{1}$ & $\mathbf{D}_{2}$ & $\mathbf{D}_{3}$ & $\mathbf{D}_{4}$ & $\mathbf{D}_{5}$ & & $\mathbf{D}_{1}$ & $\mathbf{D}_{2}$ & $\mathbf{D}_{3}$ & $\mathbf{D}_{4}$ & $\mathbf{D}_{5}$ & & $\mathbf{D}_{1}$ & $\mathbf{D}_{2}$ & $\mathbf{D}_{3}$ & $\mathbf{D}_{4}$ & $\mathbf{D}_{5}$ & \\
\hline $\mathrm{V}_{1}$ & 195.1 & 199.9 & 205.6 & 213.9 & 223.2 & 207.5 & 31.3 & 32.7 & 34.0 & 37.1 & 41.5 & 35.3 & 272.8 & 277.3 & 280.5 & 284.9 & 295.2 & 282.1 \\
\hline $\mathbf{V}_{2}$ & 214.3 & 221.1 & 227.7 & 235.1 & 246.7 & 228.9 & 36.2 & 38.1 & 40.2 & 43.3 & 47.6 & 41.1 & 285.9 & 290.0 & 293.7 & 298.0 & 307.3 & 295.0 \\
\hline $\mathbf{V}_{3}$ & 225.9 & 233.3 & 239.6 & 247.7 & 261.6 & 241.6 & 40.3 & 42.4 & 45.5 & 47.2 & 51.9 & 45.5 & 291.6 & 295.9 & 299.8 & 305.6 & 317.9 & 302.2 \\
\hline $\mathbf{V}_{4}$ & 206.7 & 213.1 & 220.5 & 227.9 & 238.0 & 221.3 & 33.6 & 35.1 & 36.8 & 39.3 & 45.1 & 37.9 & 279.1 & 284.2 & 287.3 & 292.2 & 303.2 & 289.2 \\
\hline \multirow[t]{2}{*}{ Mean } & 210.5 & 216.9 & 223.7 & 231.2 & 242.4 & & 35.3 & 37.1 & 39.1 & 41.7 & 46.53 & & 282.4 & 286.9 & 290.3 & 295.2 & 305.9 & \\
\hline & \multicolumn{3}{|c|}{ SEm \pm} & \multicolumn{3}{|c|}{ C.D $(p=0.05)$} & \multicolumn{3}{|c|}{ SEm \pm} & \multicolumn{3}{|c|}{ C.D $(p=0.05)$} & \multicolumn{3}{|c|}{ SEm \pm} & \multicolumn{3}{|c|}{ C.D $(p=0.05)$} \\
\hline D & \multicolumn{3}{|c|}{3.45} & \multicolumn{3}{|c|}{9.95} & \multicolumn{3}{|c|}{0.98} & \multicolumn{3}{|c|}{2.84} & \multicolumn{3}{|c|}{1.75} & \multicolumn{3}{|c|}{5.05} \\
\hline $\mathbf{V}$ & \multicolumn{3}{|c|}{1.78} & \multicolumn{3}{|c|}{5.15} & \multicolumn{3}{|c|}{0.81} & \multicolumn{3}{|c|}{2.35} & \multicolumn{3}{|c|}{1.53} & \multicolumn{3}{|c|}{4.41} \\
\hline D X V & \multicolumn{3}{|c|}{2.30} & \multicolumn{3}{|c|}{ NS } & \multicolumn{3}{|c|}{1.05} & \multicolumn{3}{|c|}{ NS } & \multicolumn{3}{|c|}{1.97} & \multicolumn{3}{|c|}{ NS } \\
\hline
\end{tabular}

Note:

D: Dates of sowing

$\mathrm{V}$ : Varieties

$D_{1}: 2$ Fortnight of June

$\mathrm{D}_{2}: 1^{\text {st }}$ Fortnight of July

$D_{3}: 2^{\text {nd }}$ Fortnight of July

$\mathrm{D}_{4}: 1^{\text {st }}$ Fortnight of August

$D_{5}: 2^{\text {nd }}$ Fortnight of Augus

$$
\begin{gathered}
\mathrm{V}_{1}: \text { GGV-05-01 } \\
\mathrm{V}_{2}: \text { RNR - } 15048 \\
\mathrm{~V}_{3}: \text { BPT -5204 } \\
\mathrm{V}_{4}: \text { GNV-10-89 }
\end{gathered}
$$


Table.4 Economics of direct seeded rice as influenced by different varieties under varied dates of sowing

\begin{tabular}{|c|c|c|c|c|}
\hline DV & $\begin{array}{c}\text { Cost of cultivation (Rs. ha } \\
1 \text { ) }\end{array}$ & $\begin{array}{c}\text { Gross returns (Rs. ha } \\
1 \text { ) }\end{array}$ & $\begin{array}{c}\text { Net returns (Rs. ha } \\
\text { 1) }\end{array}$ & BCR \\
\hline$D_{1} V_{1}$ & 56,000 & $1,25,711$ & 69,711 & 2.24 \\
\hline $\mathbf{D}_{1} \mathbf{V}_{2}$ & 56,000 & $1,31,564$ & 75,564 & 2.35 \\
\hline$D_{1} V_{3}$ & 61,000 & $1,24,744$ & 63,744 & 2.04 \\
\hline$D_{1} \mathbf{V}_{4}$ & 56,000 & $1,23,839$ & 67,839 & 2.21 \\
\hline$D_{2} V_{1}$ & 56,000 & $1,24,965$ & 68,965 & 2.23 \\
\hline $\mathbf{D}_{2} \mathbf{V}_{2}$ & 56,000 & $1,30,502$ & 74,502 & 2.33 \\
\hline $\mathbf{D}_{2} \mathbf{V}_{3}$ & 61,000 & $1,15,057$ & 54,057 & 1.89 \\
\hline $\mathbf{D}_{2} \mathbf{V}_{4}$ & 56,000 & $1,22,546$ & 66,546 & 2.19 \\
\hline$D_{3} \mathbf{V}_{1}$ & 56,000 & $1,21,588$ & 65,588 & 2.17 \\
\hline $\mathbf{D}_{3} \mathbf{V}_{2}$ & 56,000 & $1,28,309$ & 72,309 & 2.29 \\
\hline $\mathbf{D}_{3} \mathbf{V}_{3}$ & 61,000 & $1,13,466$ & 52,466 & 1.86 \\
\hline $\mathbf{D}_{3} \mathbf{V}_{4}$ & 56,000 & $1,20,211$ & 64,211 & 2.15 \\
\hline $\mathbf{D}_{4} \mathbf{V}_{1}$ & 56,000 & $1,18,887$ & 62,887 & 2.12 \\
\hline $\mathbf{D}_{4} \mathbf{V}_{2}$ & 56,000 & $1,23,862$ & 67,862 & 2.21 \\
\hline $\mathbf{D}_{4} \mathbf{V}_{3}$ & 61,000 & $1,08,078$ & 47,078 & 1.77 \\
\hline $\mathbf{D}_{4} \mathbf{V}_{4}$ & 56,000 & $1,13,344$ & 57,344 & 2.02 \\
\hline$D_{5} V_{1}$ & 56,000 & 92,478 & 36,478 & 1.65 \\
\hline$D_{5} \mathbf{V}_{2}$ & 56,000 & 95,758 & 39,758 & 1.71 \\
\hline$D_{5} \mathbf{V}_{3}$ & 61,000 & 87,026 & 26,026 & 1.43 \\
\hline $\mathbf{D}_{5} \mathbf{V}_{4}$ & 56,000 & 86,951 & 30,951 & 1.55 \\
\hline SEm \pm & - & 404.2 & 404.2 & 0.05 \\
\hline$\underset{(p=0.05)}{C . D}$ & - & 1213 & 1213 & 0.16 \\
\hline
\end{tabular}

Note:

D: Dates of sowing
$\mathrm{D}_{1}: 2^{\text {nd }}$ Fortnight of June
$\mathrm{D}_{2}: 1^{\text {st }}$ Fortnight of July
$\mathrm{D}_{3}: 2^{\text {nd }}$ Fortnight of July
$\mathrm{D}_{4}: 1^{\text {st }}$ Fortnight of August
$\mathrm{D}_{5}: 2^{\text {nd }}$ Fortnight of August
$\mathrm{V}$ : Varieties
$\mathrm{V}_{1}: \mathrm{GGV}-05-01$
$\mathrm{V}_{2}$ : RNR -15048
$\mathrm{V}_{3}$ : BPT -5204
$\mathrm{V}_{4}: \mathrm{GNV}-10-89$

The results also revealed that the interaction effect of RNR-15042 sown on $2^{\text {nd }}$ fortnight of June recorded higher gross returns, net returns and also BCR (Rs. 1,31,564 ha ${ }^{-1}$, Rs. 75,550 $\mathrm{ha}^{-1}$ and 2.35 , respectively) which was found on par with RNR-15048 sown on $1^{\text {st }}$ fortnight of July (Rs. 1,30,502 ha- ${ }^{-1}, 74,488 \mathrm{ha}^{-1}$ and 2.33 , respectively. Whereas lower gross returns, net returns and also BCR was recorded by BPT-5204 sown on $2^{\text {nd }}$ fortnight of August (Rs. 86,951 ha ${ }^{-1}$, Rs. 26,013 ha ${ }^{-1}$ and 1.43 , respectively). Comparatively, there was good growth and yield parameters, thus better grain and straw yield observed in early sown crop which led to higher gross returns, net returns and benefit cost ratio. Even the market price for RNR-15048 was high thus economic returns is high. These results are in conformity with the findings of Dawadi and Choudhary, 2013 and Satapathy et al., (2016). 
In conclusion from the experiment we can conclude that, among different treatments, GGV-05-01 sown on $2^{\text {nd }}$ fortnight of June recorded higher NPK content and uptake, as there was higher biomass. But economic returns is of great importance to the farmers. The results showed that RNR-15048 sown on $2^{\text {nd }}$ fortnight of June is best sowing date as it recorded higher gross returns, net returns and also BCR.

\section{References}

Anonymous, 2018, Directorate of Economics and Statistics.htpp:/ www.indiastat.com

Bouman, B. A. M., Humphreys, E., Tuong, T. P. and Barker, R., 2007, Rice and water. Adv. Agron., 92: 187-237.

Chamely, S. G., Islam, N., Hoshain, S., Rabbani, M. G., Kader, M. A. and Salam, M. A., 2014, Effect of variety and nitrogen rate on the yield performance of boro rice. Progressive Agric., 26(1): 6-14.

Dawadi, K. P. and Chaudhary, N. K., 2013, Effect of sowing dates and varities on yield and yield attributes of direct seeded rice in chitwan condition. Int. J. Agric. Sci. Res., 2(4): 095-102.

FAO, 2004. Rice and Us. Food and Agricultural organization of the united nations, Rome, Italy.

Jehangir, W. A., Masih, I., Ahmed, S., Gill,
M. A., Ahmad, M., Mann, R. A., Chaudhary, M. R., and Turral, H., 2005, Sustaining crop water productivity in rice-wheat systems of South Asia: a case study from Punjab Pakistan. In: Draft Working Paper. Inter. Water Manag. Ins., Lahore, Pakistan.

Naresh, R. K., Gupta Raj, K., Singh, B., Kumar Ashok, Shahi, U. P., Pal Gajendra, Singh, Adesh, Yadav, A. K. and Tomar, S. S., 2010, Assessment of no-tillage and direct seeding technologies in rice-wheat rotation for saving of water and labor in Western IGP. Progr. Agri. Int. J., 10(2): 205218.

Satapathy, B. S., Pun, K. B., Singh, T. and Rautaray, S. K., 2016. Influence of dates of sowing on growth and yield of direct wet sown early Ahu rice (Oryza sativa L.) varieties under flood prone lowland ecosystem of Assam. Ann. Agric. Res. New Series., 37 (1) : 30-35.

Singh Samar, Sharma, R. K., Govindra Singh, Singh, S. S., Singh, U. P., Gill, M. A., Jat, M. L., Sharma, S. K, Malik, R. K., Josan, A. S. and Gupta, R. K., 2005, Direct seeded rice: A promising resource conserving technology. RiceWheat consortium for the IndoGangetic Plains, New Delhi.

\section{How to cite this article:}

Shanta, C. M., Y. M. Ramesha, D. Krishnamurthy, M. R. Umesh and Manjunatha Bhanuvally. 2020. Effect of Sowing Dates and Varieties on Economics and Nutrient Status of Direct Seeded Rice (Oryza sativa L.) and Soil. Int.J.Curr.Microbiol.App.Sci. 9(07): 1651-1657. doi: https://doi.org/10.20546/ijcmas.2020.907.190 